\title{
We Have Plenty of Water, Don't We? Social Norms, Practices, and Contentions in a Drought-Ridden Country
}

\author{
Angela T. Ragusa (D) \\ Faculty of Arts \& Education, Albury Campus, Charles Sturt University, Bathurst 2640, Australia; \\ aragusa@csu.edu.au
}

check for updates

Citation: Ragusa, A.T. We Have Plenty of Water, Don't We? Social Norms, Practices, and Contentions in a Drought-Ridden Country. Hydrology 2021, 8, 161. https:// doi.org/10.3390/hydrology8040161

Academic Editor: Alain Dezetter

Received: 8 September 2021

Accepted: 22 October 2021

Published: 25 October 2021

Publisher's Note: MDPI stays neutral with regard to jurisdictional claims in published maps and institutional affiliations.

Copyright: (C) 2021 by the author. Licensee MDPI, Basel, Switzerland. This article is an open access article distributed under the terms and conditions of the Creative Commons Attribution (CC BY) license (https:// creativecommons.org/licenses/by/ $4.0 /)$.

\begin{abstract}
Climate and land use change pose global challenges to water policy and management. This article furthers calls for integrated research conceptualizing water management as a holistic, interdependent system that may benefit from sociological research. To better understand how socioenvironmental change affects lifestyle expectations and experiences, interviews with in-migrants (relocated to inland Australia from metropolitan cities), industry and government informants are thematically analyzed. Results show in-migrants engage in adaptive water management and conservation strategies to enhance water security, yet call for council provision of water management education to minimize vulnerability. Industry informants perceive few water supply or pollution issues, favoring technological solutions to support unfettered growth and water amenities, while de-prioritizing environmental sustainability goals. Government priorities reflect drought narratives in Australian water policy reform and show concern about meeting consumer water supply and preserving water quality. With predictions of greater weather severity, including flooding, and in-migrants' difficulty managing heavy rainfall, national legislation and policy modifications are necessary. Specifically, normalizing climate variability in policy and social identities is desirable. Finally, practices prioritizing water scarcity and trading management over environmental protection indicate a need to surpass environmental commodification by depoliticizing water management.
\end{abstract}

Keywords: water management; demographic change; consumption; lifestyle migration; social perceptions; water policy; environmental sociology; identity

\section{Introduction}

Sustainable development and governance depend on policy informed by social perceptions and norms, in addition to environmental and economic practices. Water management is one area where research and theory show individual consumption practices are influenced by factors beyond information. Merely advocating for 'more' information is a well-established limitation of deficit theory. This limitation extends to water and other environmental policy [1]. Knowledge variability co-exists with global variation in population awareness, and social valuing, of the environment as a water priority [2]. In Australia, limited social research investigates competing water governance frameworks. Reviews deduce that differentiating between neoliberal and environmental ideologies reflects institutionalized water policy [2]. Colonialism, federalism, agrarianism, and economic rationalism are legacies with continued relevance for understanding the history of Australian water reform [3]. Further benefit, however, exists to questioning how micro-sociological features, namely identity and narrative construction from life experience and positionality, mediate systemic conditions.

Australian water policy reform failure is framed as an ideological impasse between politicized irrigation and environmental interests [4]. Water management change requires greater ecology and planning expertise, two of several factors necessary to influence adaptation and monitoring compliance [5]. Situating water management within a population studies framework may thus highlight societal expectations about water derived from 
Western lifestyles. For example, the Murray Darling Basin (MDB) is Australia's largest river system. This system garners copious political focus in the research location. The federal government's MDB adaptive management strategies, in seeking to address climate change in response to the hottest and driest years recorded in the research area [6], also reflect social priorities. For example, key government foci are hydrology, ecology, water markets and economies, water quality, and operations; social factors are excluded [6]. This omission characterizes much water research.

Water research reflects traditions of framing scientific problems independently from social problems. Endemic in the history of science, particularly science conducted to inform policy, is the problem that environmental issues (including climate change) embody complex social relationships involving knowledge, policy construction, power, and vested interests [7]. With the Millennium drought broken by flooding, the Australian water policy literature acknowledges the need for better adaptative strategies and government policies. Much water research, however, continues to focus on hydrology [6]. Hence, calls to surpass political narration of drought and flooding as "exceptional events" because climate change exacerbates patterns of oscillating water availability [8] (p. 649) may benefit from socially contextualizing water narration. This article begins furthering insight about the social construction of water issues by exploring how social norms, identities, and experiences affect water perceptions and, subsequently, water narrations.

European and American research studies show the sociological nature of natural resource management policy. Western lifestyles and consumption culture promote climate change and policy responses, yet these "depend on people's willingness to accept the policy prescriptions" [7] (p. 928). Lifestyle decisions profoundly affect hydrology. Historically, water availability and affable environmental conditions coincide with human settlement patterns [9]. Today, however, population movement is conceived as individualistically decided and economically driven according to a sizable literature informed by microeconomics [10]. Although the limitations of economics for understanding migration patterns and environmental change are emerging [7], a dearth of research still exists [11]. Migration decisions and environmental conditions affect natural and built environments and livability [12,13]. Nevertheless, migration theory deprioritizes environmental change [14]. Hence, this article also contributes to the emerging literature advocating environmental prioritization in population studies. Specifically, the qualitative sociological thematic analysis of 27 interviewees' water perceptions and practices in southeastern Australia offers exploratory insights for policymakers and interdisciplinary audiences about tensions between population growth and water management.

Managing population change requires improving water management and negotiating consumption practices. Urbanization showcases human-water migration dynamics as interdependent relationships between cities and hinterlands [10]. Urban-rural interdependence is apparent in the rapid population growth of rural and semi-rural areas bordering Australian cities. Australian rurality inadequately offers infrastructure and services to meet population growth. Thus, rurality relies on urbanity to supply systems and services, whilst peri-urban neighbors absorb industry and urban waste [12]. Rural-urban dynamism also affects water supply and quality. Little regard to the history of water systems, however, exists. Akin to American 'Dust Bowl' experiences, Australia's reliance on European agricultural practices persists despite long periods of drought interspersed with flooding. Long-term forecasting predicts extended drought, reduced rain coupled with flood events, and hotter days [13]. Given national statistics document population growth's increased water consumption [14], the social implications of water availability are vital to humans, production practices, and ecosystems.

Environments affect community livability. "Challenges such as urban sprawl, climate change, fiscal challenges, water shortages/drought, [and] regional hot spots of rapid and chaotic growth" [15] (p. 712) detract from livability [16]. Global policymakers call to approach biodiversity and ecosystems as holistic systems, conceptualizing health and issues such as climate change, energy, and water, as interconnected [17]. 'Interconnected 
systems' is a framework offering scope to improve sustainability holistically. In Australia, however, environmental prioritization is underrealized. Water competes for government funding and public interest. Urbanization reduces humanity's environmental connection and values that support conservation, contrasting with rural counterparts [18]. Failure to meet global sustainability goals partly derives from social norms and conditions. As Australian public health policy and policing of COVID pandemic and vaccination efforts reveal [19], geographical isolation and compartmentalization persist in strategizing crisis governance. Similarly, irrigators and ecologists fiercely debate water allocations using crisis-management discourse. Policy solutions that avoid localized crisis-management strategies are required to offset social norms presuming the government's provision of safe and boundless potable water [20].

Compartmentalizing water policy, planning, and service-delivery furthers 'metrocentric' tendencies sustaining rural disadvantage [21]. For example, rural water and air quality, and their monitoring, show rural de-prioritization and failure to meet global health recommendations compared with metropolitan Australia [22-24]. Rurality poses greater health, environmental, and mortality risks from poorer service delivery, infrastructure, and socioeconomic amenities [25-30]. Remoteness increases disadvantage [31]. Heavy rural industries, especially metal and mining, drive the nation's economy and contribute to Australia's environmental degradation and biodiversity loss, despite compliance mechanisms established to enforce global standards [32]. Social practices (colonial land management and poor conservation) exacerbate Australia's poor soil quality and fragile landscapes susceptible to erosion, furthering global biodiversity and extinction crises from humanity pressuring native ecosystems [33]. Agribusiness and intensive livestock management replace family farming. Research shows this is due to global market competition, climate change, and the economic advantage that converting arable land into low-density suburban residential housing brings to supplement farmers' retirements [34-38]. Amidst sustained political and legislative change in MDB water rights, these population and land use changes exacerbate water unavailability and environmental degradation [39].

Greater investigation of water perceptions and practices is vital to create better systems and societies. Changing adaptation practices may improve socioenvironmental health affected by water mismanagement and scarcity in changing rural landscapes [40-42]. Scientists worldwide document the urgency of policy and adaptive strategies to reverse biodiversity loss and extinction rates. This necessitates meeting United Nations Sustainability Goals for water health [43]. Environmental factors are also central to global livability indicators for community planning and health $[12,15,44-48]$. Enhancing livability demands addressing metrocentric and metric-based research biases. Changing landscapes reflect divergent water interests, narratives, and practices set within a political climate of water brokering and commodification [39]. As micro-sociological water interpretations exist within, and are influenced by, social systems, focus must surpass urban water management assessment and evaluation to deepen extant insights [49]. This article examines water dynamics facing metropolitan and rural-regional Australia. It presents qualitative, sociological insights gained from in-depth, face-to-face interviews with informants employed in government and industry, and in-migrants who relocated to a rural-regional inland area (RRIA) from metropolitan Australia. Results show social roles and identities shape water priorities and perceptions relevant for integrating water management, minimizing urban sprawl, and identifying interdependent water supply and planning relationships [50,51]. Although changing water, environment, and population conditions affect livability $[49,52,53]$, ultimately, the article argues water management must be divorced from its commodification.

\section{Materials and Methods}

In-depth face-to-face interviews permit gaining expansive insight about water issue salience and experience as social phenomena $[54,55]$. This method also supports investigating place-based decision making, norms, and sociocultural identities related to 
in-migration [56]. The human research ethics approval protocol number is 103201210 and there is no external grant funding to report. The research design is informed by government policies rigorously promoting urban decentralization to grow and retain regional-rural Australian populations $[57,58]$. The RRIA's location exhibits slow population growth, consistent with many rural-regional Australian locations, compared with the nation's two most rapidly expanding metropolitan and peri-urban areas-Melbourne and Sydney. Hence, the research focuses on the nation's two most populated and rapidly urbanizing states, New South Wales (NSW) and Victoria (where Melbourne and Sydney are located). Metropolitan informants derive from these states. The RRIA receives much in-migration from these two metropolises and is in south-western NSW and north-eastern Victoria (350-550 km to Melbourne or Sydney). Statistics show the RRIA exhibits rural-urban migration fluidity over time [59].

Recruitment utilized web-searching of government, industry, and community sites to locate informants in planning, policy, and management. Following social research methods' protocols for locating less visible populations [55], snowball and purposive sampling strategies $[60,61]$ helped locate the RRIA residents who relocated from metropolitan Australia for lifestyle-seeking purposes. In contrast with informants, the RRIA residents had no environmental policy or water management expertise. Interview selection criteria include being over age eighteen, occupying professional/community role(s) for $>12$ months, residing in the research location, and participating voluntarily. Interviews occurred in offices and community spaces. Participants at remote properties participated by telephone. Data were digitally recorded, transcribed verbatim, and stored in password-protected files to achieve ethics compliance.

Interviews collected demographic and substantive data to further knowledge about water, community change, and environmental impacts. A semi-structured schedule allowed flexibility to garner insights from participants with differing expertise and social roles. It also ensured sufficient consistency across participants to identify data patterns [60]. Seven interview questions are analyzed for this article. Questions 1-3 relate to informants and 4-7 to in-migrants. 1. How do you think community growth is going to environmentally impact the community? 2. Where do you think most water will come from, and is there enough, for the growing population? 3 . What services/infrastructure requirements are needed for future populations? Do these services and infrastructure currently exist? Why or why not? 4 . What factors were involved in your decision-making process about where to live? 5. What adaptations, if any, have you had to make since moving to a rural environment? 6. What are the top positive/negative aspects of your relocation? 7. What are your future intentions?

Data analysis employs an interpretive analytical process. Methodological developments in microsociology and interpretivist theory and methods [62] support research seeking to deepen knowledge about societal perceptions and actions that affect water resources and management (ecologically and anthropocentrically). This analysis follows constructionist methodology [63] by explicating participants' perceptions about the social context surrounding water availability, consumption, priorities, quality, management, or challenges associated with population change in the research location. Following Neuman [55] (p. 84), the theoretical framework places social phenomena "within an entire worldview and system of meaning. Each person's subjective worldview shapes how he or she acts, so the goal is to discern others' reasoning and view of things". Subsequently, the analysis does not seek to generalize or extrapolate results. Rather, it provides insights construing water as part of broader social meaning-making systems for policymakers, planners, and communities experiencing population change.

Analysis began with a coding scheme seeking to authentically capture participants' perceptions about water and trends across interviews following interpretivist methodology and constructivist grounded theory [62-66]. Six preliminary themes emerged. These were reviewed for content overlap. Transcript re-reading produced another major theme. Subsequently, two preliminary themes were collapsed. Repeating this process achieved 
theoretical saturation [66]; neither adding nor reducing the final three themes augmented understanding participants' perspectives about water across the dataset [54,55]. These themes reveal challenges and solution-aimed water practices amid population and landscape change in the research location. Results present demographics and thematic findings. Data quotes for informants appear as KI-M-\# or KI-RRIA-\# ('M' refers to metropolitan compared with the RRIA). The '\#' corresponds with interviewees' identification numbers. Where 'IM' precedes identification numbers, this shows the data quote is from an in-migrant, rather than an informant.

\section{Results}

\subsection{Interviewee Demographics}

Demographics for the 27 interviewees appear in Table 1.

Table 1. Interviewee demographics.

\begin{tabular}{ccc}
\hline Demographics & $\begin{array}{c}\text { Government/Property } \\
\text { Industry Informants } \\
(\boldsymbol{n}=\mathbf{1 5})\end{array}$ & $\begin{array}{c}\text { In-Migrants * } \\
(\boldsymbol{n}=\mathbf{1 2})\end{array}$ \\
\hline Age (mean) & 49 (age range 30-63) & 49 (age range 34-67) \\
Male & $60 \%$ & $33 \%$ \\
Australian-born ethnicity & $87 \%$ & $75 \%$ \\
Married/Partnered & $74 \%$ & $100 \%$ \\
Completed graduate degree (MS, PhD) & $53 \%$ & $0 \%$ \\
Employed full-time & $100 \%$ & $100 \%$ \\
Owns residential home & $87 \%$ & $100 \%$ \\
Owns investment property & $54 \%$ & $1 \%$ \\
Planning to leave area in $~ 5$ years & $33 \%$ & $25 \%$ \\
Never lived on a farm/lifestyle block & $73 \%$ & $25 \%$ \\
\hline
\end{tabular}

* Relocated urban-to-rural/regional community residents.

Ages range from 30 to 67, with 49 the mean. Interviewees are largely Australiaborn, married with children, and own their residential home. Nearly all (99\%) owning investment properties are in real-estate, although property ownership appears unrelated to future intention to move. All in-migrants own their residential home, yet $25 \%$ expect to move in approximately five years. Most (75\%) in-migrants live on a farm or 'lifestyle' property, compared with $27 \%$ of the informants. A third of all informants plan to relocate in 5-10 years, largely due to retirement.

\subsection{Qualitative Thematic Analysis}

\subsubsection{Theme 1-Identity-Related Water Preferences and Practices}

Identity norms inform residential location choices and practices. Australian beachculture is a social identity affecting recreational water preferences and practices in urban and rural locations. Metropolitan beaches and water amenities are two environmental attributes missed by in-migrants. I miss the Sydney Harbor and the water, but I don't want to sound that I am complaining because I am not. I am enjoying what I am doing here (RRIA-IM-9). Lack of recreational water does not prevent "enjoying" rurality post-migration, yet water amenities affect migratory practices. Property industry informants note the RRIA struggles to attract and retain residents compared with metropolitan Australia. This partly is because the RRIA lacks nearby beaches available to metropolitan communities in southeastern Australia. I always think a lot of people like the cities because of the beaches ... we obviously don't have a beach here (KI-RRIA-10). Areas with beaches, however, struggle with population growth affecting fragile ecosystems. Metropolitan planners lament, the balance of retaining the amenity versus letting people in is almost unsolvable, and especially if you put a beach in front of an Australian (KI-M-3). Such tensions also exist between recreational water consumption norms and water availability in the RRIA. 
Sixty-seven percent of the RRIA in-migrants recreationally pursue hobby-farming. Hence, water supply affects location attractiveness and economic prosperity. Although the RRIA experiences intermittent drought and flooding, drought largely informs identity construction. Primary production narration frames the RRIA as necessitating dryland farming or irrigation to 'drought-proof' business. No in-migrants had farming experience before moving to the RRIA, yet farming experience affects how former urbanites selfidentify and relate to water in their new locations. Farming and rural living foster adaptive water practices, water conservation, and water independence. In-migrants note moving to the RRIA requires learning how to be self-reliant for water provision. This challenge in "drought affected areas" increases respect for largescale farming and informs decisions about capacity to water livestock. It is in a drought affected area, but when we first got there it rained a fair bit and all of our tanks have been full. We certainly had to adapt to living on tank water. That was quite easy 'cause we tried to be fairly conscious of water usage and not wasting things, even when we were in Sydney ... it is a hobby-farm. We have a couple of horses and chickens and we don't have the stock numbers like other people do, where they really have to worry about the effect of the drought (RRIA-IM-8).

Neither property informants nor hobby-farmers discuss how flooding affects land use. Water practices in the RRIA foster normative expectations that recreational water facilities will be supplied by councils for residential enjoyment. Irrespective of water availability, residents expect public spaces to look watered. Subsequently, councils report, always looking to try and reduce our own water source and demand as a Council because we have major demands on our water supply for our parks and gardens used for streets, sports ovals, so we are looking at different grass species (KI-RRIA-8). Council's provision of watered sport ovals supports social identities revolving around sports. This includes recreational water sports. Industry informants describe the RRIA as a big sporting town (KI-RRIA-15). Allowing motorized recreational vehicles in water catchment areas and desire for water-intensive facilities provided by councils exists with little industry concern for environmental water needs. I'm sporty, I want sporting facilities and I think [the RRIA] has some great sporting facilities ... and the weir is quite an attractive thing for this area, obviously growing up here a lot of my friends, family always heading out there in the summer (KI-RRIA-10). Although industry informants from the RRIA are long-term residents who lived through the Millennium drought, water narratives differ when discussing recreation and farming; farming identities and narratives evoke water shortages, whilst recreational water and amenity desires lack connections to water availability.

Aside from farming and industry, the RRIA's other major water need arises from property development. Councils and property industries actively encourage population growth, specifically urbanites' relocation for the RRIA's superb 'lifestyle'. Lifestyle expectations inform location expectations. Property informants believe water supply for growing populations is 'looked after' by local government. Council is looking after that side of things. We've definitely got that covered once again with the weir and all that sort of thing. Yeah, we've definitely got water covered (KI-RRIA-10). Consistently low water levels and algae blooms coexist with property informants' unbridled optimism and confidence that water supply will meet growth needs. Metropolitan property informants mirror rural-regional confidence about supply adequacy, faulting government for not providing access to desalinated water. A professional with sixty years of experience asserts, the water supply is adequate. The storage is just as adequate and they've built the new desalination thing ... and yet won't turn it on because it's too costly (KI-M-13). When asked if water availability is a concern for growing populations he replied, it doesn't appear to be. We don't have any water restrictions (KI-M-13).

Contrastingly, the RRIA's council informants describe sustainability challenges in meeting water preferences. We're looking at opportunities for waste-water reuse and reducing [water usage], being smart about plant species and timing when you do the watering, having that all computerized so it's not pumping during hot days, etc. (KI-RRIA-8). Metropolitan council informants also note strategic actions to manage adequate water supply, especially for industry and the economy, in response to drought. Water is a metropolitan wide problem ... 
that is why [the state] built a desalination plant ... because there was concern if we had a drought, we were down to $26 \%$ or something in reservoirs and it was getting to the stage where it could undermine the economy ... where industry wouldn't have water to operate. So, that's why the decision was taken to build the desalination plant, because the reservoirs just were pretty empty (KI-M-2).

Social expectations in places with an identity of being "well-watered", where "water is the attraction", are government challenges during drought. Drought, an event routinely described as an "anomaly", poses challenges beyond water availability; drought presents environmental challenges for populations accustomed to recreational and clean water for activities. During drought, however, fishing areas become polluted. The issue is actually pollution ... you know don't eat the shellfish ... water supply is a huge issue during the drought, so it's this sort of anomaly that what is normally a well-watered area, where water is the attraction, is a huge issue to deal with in that period when it was almost dry ... the maintenance of water ... is almost more an issue of environmental water features than it is the infrastructure of water provision (KI-M-3).

This metropolitan council, experienced in rural-regional planning, describes the social norm of rural self-sufficiency, yet cautions the RRIA about pursuing population growth since "every extra person" affects systemic balance. A lot of [rural residents] would be relying on septic tanks and rainwater collection, so there is a fair deal of self-sufficiency. [However], every extra person that comes into an area does affect it. Probably the best thing councils can do is have a really good sense of what their assets are, what it is that they are trying to protect, and it may be that they are trying to protect physical amenities or wilderness, or they are wanting that economic development ... then understanding there is a balance and ... coming from a planning background, within that you develop some sort of fairly sophisticated structure planning, frameworks (KI-M-3).

\subsubsection{Theme 2 -Water Conservation Pressures and Practices}

Climatic conditions affect water conservation. Drought visibility increases water conservation, while rain periods diminish water conservation concerns. Water's not too much of a concern right now because we've had some recent rain in the last twelve months, the problem will re-emerge again when we go into a severe drought area, a dry-spell. (KI-M-14) Most $(75 \%)$ relocated urbanites actively change water conservation habits after relocating and encountering immediate water-supply issues. Living 'on land' necessitates learning to conserve water through water management. We had to learn a lot about water managementthings like how pumps work, how plumbing works, so all the stuff about relying on your own water supply rather than turning the taps on from the mains ... had to learn some aspects of growing things in this particular climate (RRIA-IM-11).

Lack of infrastructure necessitates water conservation, however, regardless of 'lifestyle' preferences or environmental concerns. We are more conscious of our water usage because we supply our own water. Our house is solar passive so we use the house in a way that maximizes its heating and cooling (RRIA-IM-10). This hobby-farmer relocated to a property amongst largescale farmers. This made several adaptations necessary since the climate bifurcates between drought and flooding. We have extra water tanks because when we get a lot of rain, we tend to lose it and then have long periods when we don't get rain. So, we had to think about how much we can store water. We reuse all our sewerage water. We have sewage treatment systems that we reuse all the water. Our gardens are tolerant to drought and we have short showers, and not very many animals. We have alpacas which we keep the numbers very low. We don't need to buy water for them (RRIA-IM-10). Likewise, another describes, we are out of town. We don't have town water. I think we learn to live with drought conditions a lot quicker than people in Sydney do because we are always thinking of ways of saving water and showering. Having children and washing -it was a big adaptation for us to change to that mentality after having water on tap (RRIA-IM-12).

Although most in-migrants do not rely on farming for their household income, water unavailability still creates "vulnerable" feelings. The drought has been unfortunate-lack of water availability-having [to manage] your own water puts you in a vulnerable position 
(RRIA-IM-11). All rural-regional government officials agree water conservation is a matter that every local government area should be dealing with (KI-RRIA-8). Water conservation is one of two major environmental sustainability campaigns led by rural-regional councils in response to population growth. We're really pushing at the moment to halve the waste [and] save water ... there's a couple of campaigns happening currently (KI-RRIA-1). Community growth is putting pressure on council budget ... with more residences, there needs to be more money spent on sewerage, plumbing, drainage etc. and that's reducing funds for other alternate investment or activities ... [that] could affect the environment (KI-RRIA-1). While the RRIA does have the [water shortage] concerns of locations further west, local government thinks we could be a lot wiser with water... water restrictions come in far too late ... we have to be a lot more smarter with the resources that we have (KI-RRIA-1).

The RRIA councils agree water conservation is a priority to serve human populations. Councils vary in planning and managing water conservation through population growth strategies. One government informant notes according to the Australian Bureau of Statistics, economically affluent places in the RRIA have greater water conservation measures. Even the most affluent regional city in the RRIA, however, highlights economic constraints affect water conservation practices and planning. We have master plans for residential growth areas ... we know we can feed to the right services for water and sewer, and at a feasible cost. Sill if there are too many pumps required, you just can't do, you just can't allow for it, so everything needs to be planned ... and appropriate open green space within that large growth area to cater for the next 50 years of residential growth (KI-RRIA-8).

Councils' water sustainability foci prioritize industry and built environments (i.e., parks/sport ovals), not environmental conservation. This normative practice underscores local government's perceived role in community water provision. We have to take into account for jobs, allowing for industrial growths areas ... we've actually got an integrated water cycle management program for industrial growth area for large and heavy industry. There is opportunity to reuse some of the treatment water that is used at the major business ... perhaps be reused for processed water of other industries. It is very comprehensive. We have to allow for sewerage treatment plants and pumping stations and we already know where we are going to have to create new pumping stations and expand the treatment plant. We are looking to water, waste-water reuse on parks and gardens and the effect on ... particularly sports ovals and assessing the long-term effect that they may have on soil strata and plant species (KI-RRIA-8).

Hobby-farmers differ from councils in water conservation priorities. They seek to connect land and water management, want Councils to improve natural resource education, and call for legislative responsibility in managing climate and land-use. It would be good to have a greater awareness of land management ... the place we own is small [yet] we've tried to develop this property so we don't have tape weed and we don't have Patterson's curse ... we have very few rabbits these days because we have tried to do something ... with natural means rather than chemical fertilizers. It would be nice if Council could help to push that and help develop it around the countryside. Education is the way to do it-put funds into ... land and water management programs (RRIA-IM-7). As another notes, I think that the answer to climate change and the answer to Murray Darling Basin water and salinity problems is actually land management. The way we manage our land. Even the problem of climate change is due to the way we manage land. I'm 100\% convinced about that. And that's what I'm trying to do, I am trying to manage that piece of land (RRIA-IM-1).

Metropolitan informants, akin to hobby-farmers, believe local government should play an educative role in promoting drought awareness and water conservation. I think with the recent drought issues ... people are still conscious about how much water they are consuming (KI-M-11). First-generation migrants require water conservation information in languages beyond English. I think the local councils are a good point of first contact. You get all the information you need for the area you live in. Councils can provide a vast list of information that people don't seem to be aware of ... and they also provide them in foreign languages, hopefully in the language you require (KI-M-11). 
Metropolitan councils managing the RRIA also report landowner "churn" and differing residential interest in rural landscapes. There is a level of churn that happens with land ownership ... the diversity of the people buying bush blocks or ... buying a place near the snow. You actually had different groups buying in at different times for different purposes and they were both buying different products. People that wanted access to the snow were often buying a flat in [the area] so that was quite a different group from the ones who were buying a bush block. Those people were much less connected to their neighbors, that was a younger group just up for the snow (KI-M-3). Thus, the micro-sociological insight themes one and two provide require systemic contextualization.

\subsubsection{Theme 3-Systemic Nature of Water Availability}

The systemic nature of water availability differentially impacts locations. Desalination is a costly solution to urban water supply issues and is unsuitable to rural-remote needs. There's these desalination plants that we are paying for, for the next thirty years, so we've got all these sort of facilities but, at the end of the day, I don't know how well these infrastructure developments they've done are going to service some of those remote areas and I think they're still going to be very much reliant on what water comes down the rivers and creeks and what can be fed into the towns (KI-M-14).

Since water availability affects farming profitability and succession planning, irrigation and water licensing prompt debate across industries. I think they are just changing their ways. We're quite lucky where we are because agriculture in this area is quite stable ... In other areas, I know farmers are having to sell up and there is no one in their family wanting to take [the business] over, but we are quite lucky here because we do get quite a high return for the land that we farm in this area ... the Murray Darling Basin has been a big debate in this area, about irrigation and how much water and things people can and cannot have and water licenses, so that has caused some concerns and pressures in the agricultural sector (KI-RRIA-1). Another notes, [water is] a factor, for sure. We're getting people from [rural area] who rely on irrigation, you know a huge amount of water to survive and grow their crops, and that is a big talking point, and getting harder. [They] are selling up and moving to [regional-centers] where, you know, water is not the main concern. It is getting tougher for the farmers, that's for sure (KI-RRIA-7).

Drought and low water allocations reduce agriculture production, continue skills shortages, and contribute to housing depreciation in small communities where property interest depends on agricultural profit or metropolitan investors. Traditionally, this center... has always been struggling to attract people with the skills ... this region is a strong agricultural producing area, so when they had the drought and also low water allocations, that reduced production from an agricultural perspective quite significantly, so then people moved away. People were selling and so the [housing] prices dropped. Before the significant downturn with drought and water allocations, the housing [market] was relatively small ... I bought for very little money and then I sold it to investors that were from Sydney (KI-RRIA-6).

Industry informants describe family farming's demise as private networks amalgamate smaller properties into larger holdings. Those exiting rural Australia tend to be, on a couple of hundred acres and the neighbor next door buys up a couple of hundred acres to add to their 500 acres they've got already ... mainly, it's word of mouth ... the majority would be in that scenario (KI-RRIA-7). Although changing rural landscapes generate diverse growth opportunities, agribusiness remains the primary employer outside of service industries, namely education, attracting in-migrants to areas lacking "natural resources". I don't think the natural resources of the town would be something [attracting in-migration]. It would be attractive for industry and work opportunities [as] the major reason. There is always the education sector looking for good quality teachers, but agriculture would be the main one and on different levels, like primary and secondary agriculture. By that I also mean working in the industry in wineries ... skills required on farms and there is always a need for agribusiness managers (KI-RRIA-15).

Rural business owners raise arable land subdivision as a socioenvironmental and water supply problem. Informants believe local government inadequately addresses these problems and fails to listen to community consultation or landholders. Community 
consultation, to actually listen ... Council could be more proactive. Council could really think about the subdivisions. They're looking at hundreds of subdivisions. The blocks are tiny and there aren't enough resources here at the moment for the people they really want to have the subdivisions for. There aren't services ... for these massive subdivisions. They really should take this into account and also the environmental impact for the future of climate change. I don't think the Council cares because there was a subdivision up the road and a huge amount of blocks. Some of those houses had to have water tanks, which is absolutely insane because one subdivision would have doubled the population of town. Where the hell is the water coming from? We had three years of drought and only just got through. So there's a whole heap with issues that need to be factored in by Council. Do they have solar? Do they have water tanks? They need to be almost self-sufficient in a small country town (RRIA-IM-2).

Farmland's transformation into residential developments with larger blocks being reduced down to smaller blocks and subdivided (KI-RRIA-6) refashions regional towns. This causes demographic change and transforms rurality into sprawling suburbs. Compared with farms, property informants speak of sufficient water availability in regional centers because councils regulate water affordability. The precariousness of water affordability, however, concerns informants. Water is getting more expensive as it becomes a commodity ... As you get further out of [regional centers], it's a different scenario with farms an hour of so out or more. But in the actual regional-city area, at this point in time, it [water] is affordable, but that may change down the track depending on what council requirements are (KI-RRIA-7). Another notes, rhe price of water in these [rural] areas, because people have to buy water for irrigation, the price of water was extremely high. It has come down but its edging up again (KI-M-14).

Water availability and regulation also affect migration decisions. All he was interested in was that there were no water restrictions and that he had fast broadband so he could do his business in Europe. He had no conceptions, but I told him it would be like going out to the desert (RRIA-IM-3). Similarly, a construction worker moved to a rural lifestyle block in the RRIA because, when I was looking it was fairly dry, a bit like it is now, but up in [the location] there was still a reasonable amount of water (RRIA-IM-5). Eurocentric norms thus continue guiding practices, despite relocating to dry, inland Australia. Aesthetics of bountiful green lawns and sufficient water supply inform beliefs about transforming farmland into suburbia. An in-migrant who previously lived in Europe and America describes the family responded to drought by trying to make a grey water system to water the lawns (RRIA-IM-4), rather than replace lawns. Water usage norms also affect commercial consumption.

For example, a trout farmer's experiences show cultural perceptions about water divide communities, we didn't have a large farm ... there was an issue with water there, and always has been. The trout farm was perceived to be a pollutant and a consumer of water and therefore the dairy farmers could not use it for irrigation ... it was a future that we saw in food resources, rather than ocean-catch fish with the numbers depleting in wild fish, we believed it was an ongoing prospect (RRIA-IM-6). Here, dairy-farmers feel water supply disruption threatens their livelihood. For the in-migrants, this hobby-farm results in community out-casting, local people stealing our fish at nighttime. We were not invited to anyone's BBQ or anything like that, we were still the outsiders (RRIA-IM-6).

Systemic water availability problems spur pro-active and inert management responses. To reach those who do not 'care', a German migrant farmer of vast dryland acreage advocates teaching by example. I think it's the willingness of people. Once they are willing, they learn very quickly. Like one of my neighbors. I have to say he's a good friend, but he's just not willing. He doesn't care. And if I could get him to be willing to see that he could contribute towards a solution of the problems we are finding out, he would be very capable of learning it within say two months. Getting people to see the problem. I think all you can do is be an example with your land (RRIA-IM-1).

Another systemic challenge, which metropolitan demographers raise, is population growth. Government policy responses to population challenges include making developers contribute to heritage and environmental-amenity protection, though this can produce "tension". There is also a push to try and protect the heritage values of buildings or to protect 
environmental values and amenities in the area, so there is a bit of a tension happening there. I think it's probably going to be a cost to the council. My council ... just finished consultation on the developer contributions ... a big schedule that says this is what we are going to ask of developers, and ... we're talking about a town that is going to become the largest in that municipality when growth is done (KI-M-12). As an industry informant notes, water is not regulated like a lot of other industries. There are water brokers that have the rights to capture the water and then sell water off, but I don't know if it's regulated too much by government (KI-M-14).

\section{Discussion}

Policymakers may benefit from sociologically investigating water norms and practices. Although legislation and policy hinge on social perceptions, norms, and interactions, most hydrology research focuses on natural scientific elements. This article contributes a sociological investigation of water perceptions and practices in south-eastern Australia. Micro-sociological insights emerging from qualitative methodologies [67] and environmental studies [68] may deepen understanding norms and perceptions relevant to water decision making. Although some environmental sociology shows rural residents lack institutional trust [68,69], current results find residents and industry overly trust local governments' water management capacity. Contrastingly, government informants express need to conserve and differently allocate water to meet recreational desires, population growth, and industrial usage. Disparate perceptions and water management practices highlight the need to better align community water goals and delivery management systems.

Abundant recreational and industrial water supply, coupled with rural-regional suburbanization, attracts migration to dry, inland areas. Although residential development may mitigate rural population decline from aging, farm cessation, or out-migration [70], European and metrocentric water practices exacerbate land-use conflict, environmental degradation, and institutionalized inequity [34,71]. Rural-regional landscapes require further water policy reform. 'Scarcity' is the overriding narrative interviewees use to frame water issues and concerns. Adaptive strategies and government campaigns promote water conservation. Historical analyses show water scarcity predominates national drought policy, infrastructure investment, and adaptation strategies, yet is poorly transferable to flooding [8]. In-migrant and agribusiness experiences of flooding, as part of changing weather cycles, illustrate new national narratives must inform water policy. Severe flood events require inclusion in decision making and be relabeled 'normative' experiences on the road to increased global water scarcity due to climate change $[9,12]$.

Further, the absence of Australian water policy and adaptive strategies that conceptualize flooding beyond atypical 'natural disasters' [8] shows the need for policy and discourse reflecting today's climate realities to mitigate risk. Sustainable development and production paradigms (including agriculture) may face social challenges unanticipated by scientific modeling. Research [34] argues the potential for adapting European frameworks, such as multifunctional agriculture, to Australian landscapes faces environmental degradation, population growth, and water security issues. Politicized discourse, entrenched rural practice, and de-regulated environmental protection risk reproducing systemic preferences that inequitably allocate water access and consumption.

Social roles affect water perceptions. Property developers, real-estate agents, construction workers, and community development board members describe technological solutions and population growth's viability, whilst minimizing water availability, quality, or usage concerns. Those formally educated in environmental science or town planning and hobby-farmers, united by hands-on water management experience, show concern about water availability and advocate practice change. These results further research showing experience changes environmental risk perceptions and attitudes [12,72]. Relocated urbanites who actively and voluntarily pursued hobby-farming called for educational support from councils to learn land and water management as they struggled with self-provision. This adds to research showing water knowledge determines individual motivation and engagement in water conservation [73]. Those deprioritizing water conservation had little 
hands-on experience or formal education in water management. Deficit theory critiques assert education is insufficient to change behavior [1]. Considered alongside ongoing objections to recycled water [73], the institutionalized strength of industrial water priorities, and the cost and social reluctance towards alternatives (i.e., long-range pipeline projects for inland spaces, reclaimed water, and desalinated water in metropolitan areas) show novel approaches to water variability are crucial. Extensive literature documents rurality's poorer infrastructure and socioeconomic conditions disadvantage human and environmental health [24-30]. Where rural-regional environmental degradation derives from poor water quality or reduced compliance with international standards [20], results suggest conditions will not be assuaged by existing norms and priorities.

Rural council submissions to a national inquiry about water reform objectives (i.e., national policy facilitating efficient water use and innovation, transparent policy, statutorybased planning, water security) illustrate criticism for "prioritising water trade over the protection of the environment", "enabling downstream agricultural development that has not taken into account the environmental, social and economic impacts of delivering the extra water" and "the lack of understanding of the interdependence" of industries [74]. These critiques mirror findings. De-prioritizing environmental water supply supports population and economic growth. Without holistic understanding of water management, rural council calls for water reform to support "transition to a drier and more variable future climate" and prioritize "irrigated agricultural production in the national interest" [74], echoes policy feedback and results showing that competition between environmental realities and industrial desires informs water identity construction and practices.

Irrigation is an issue where social norms and identities collide. Water supply regulation, water commodification, and market competition compete with sustainability goals. Rural-regional policy promotes population growth to encourage economic growth, despite councils stating population growth is a leading cause of water consumption needs, a finding consistent with research $[33,75,76]$. Pragmatic and politicized systemic tensions exist alongside water research revealing environmental focus at the expense of social or economic examination [77]. Similarly, water research reveals that technological innovations in agricultural irrigation aim to increase global water efficiency, yet projected irrigation demands are known to further biodiversity loss, increase salinization, and degrade ecosystems [78]. Improving water conservation requires the sociopolitical reasons underscoring the policy and management of water irrigation, and industry practices, be revisited.

Interviewees note irrigators influence local water supply and commodification. Water commodification creates precarious rural economies and unviable communities. In a location where "large irrigators appear to be taking water over which they don't have rights and selling it outside the markets to farmers of walnuts and other thirsty crops, leaving dying rivers in their wake" [39], traditional farming practices exacerbate water supply problems. Contrasting with property developers and traditional farmers' valuing water primarily for its productive or amenity value, ex-urbanites' value pro-environmental water conservation. The social value of water thus may exceed its existence as an economic product, a commodity to be exchanged in a market. Australian water policy analysts describe water as a deregulated financial instrument facilitated by policy that, "removed restrictions on who could own and trade water rights ... exempting traders from regulation that would normally apply to financial markets and markets for commodities. External traders used tactics no one anticipated including market manipulation and high-speed trading ... [supported by] tax advantages and subsidies that drive water rights away from the best land toward arid lands far down-river ... a giant policy experiment [that] is sucking hundreds of millions of dollars each year out of the Murray-Darling Basin, and it is sending water away from our most productive land and what used to be our most vibrant food-bowl communities" [39]. Changing this sociopolitical condition requires norms, identities, and practices that shape, and are shaped by, environmental realities, not technological aspirations. 
Water norms and practices reflect intensified commodification, increased cost, and environmental de-prioritization. Drought's impact on rural economies, communities, and migration patterns is well established in American and Australian history [79]. Achieving United Nations' sustainability goals, however, demands water policy, legislation, and management re-evaluation. Lifestyle and socioeconomic preferences drive the conversion of arable land into suburbia, creating urban sprawl, extending peri-urban areas, and reducing water and land for food production [80-82]. The metropolitan location researched is estimated to lose " $16 \%$ of its 'foodbowl' including up to $77 \%$ of land in the inner foodbowl by 2050 if urban sprawl continues at the current rate" [80]. Meanwhile, the RRIA retains divisive perceptions about government (de)regulation of water rights. Those passionate about environmental water supply press for urgent water reform, whilst rural development advocates emphasize growth to assuage population and economic decline [40-42].

The water literature conceptualizes 'social' as user inequality [77]. Inequity, however, further appears as institutionalized identities and practices that reproduce, or fight, sociopolitical advantages governing water access. Results qualitatively evidence water availability, conservation, and priorities are embedded in social relationships reflecting power, vested interests, and agendas [7]. In water policy environments where agendas promote economic prosperity, future research may wish to apply social power and social inequality theories as outlined beyond the hydrology literature to depoliticize water management [34]. Water connects small and large communities, yet deregulation fails to support interconnected systems and water availability. This threatens species and environments [83].

Results also show examples of population change countering traditional rural sociological depictions of agrarian societies with multi-generational family farms [34,40-42,79,84-86]. This furthers critiques that most depictions of Australian agrarianism fail to reflect "the realities of rural life" because "the family farm was the creation of urban lawmakers rather than the pattern of agriculture which was emerging in the colonies" [87] (p. 25). They also do not reflect today's farming realities. Hobby-farmers make livestock decisions informed by water availability and actively manage water supply by selecting animals requiring less water consumption (i.e., alpacas) or reducing numbers. Yet, they describe their practices as 'different', sociologically counterhegemonic, to traditional farming in the RRIA. This social condition left some feeling 'outcasted' by rural communities embroiled in irrigation and climate change debates, underscoring the tenacity of 'country-mindedness' as an ideology perpetuating urban-rural division and detracting from integrated land and water management. Geographical identity construction within communities perpetuates metrocentric biases and rural disadvantage noted in policy research $[21,87]$. Theoretically, rural reification requires dismantling. Water perception, experience, and knowledge heterogeneity within communities and among residents supports the literature showing divergent environmental management capacity and interest amongst 'new' rural-regional residents [36-38]. Practically, audits critique state government development planning for inadequately considering climate change and water infrastructure in rural-regional areas since 2014 [88]. Thus, creating policy and legislation that addresses divergent water practices and enacts responsive management strategies is long overdue.

Funding: This research received no external funding.

Institutional Review Board Statement: The study was conducted according to the guidelines of the School of Humanities and Social Sciences Ethics Committee of Charles Sturt University protocol code 103201210 approved 6 November 2012.

Informed Consent Statement: All subjects provided informed consent.

Data Availability Statement: In accordance with Human Research Ethics Committee approval, data cannot be made publicly available to protect participant confidentiality.

Acknowledgments: Acknowledgement is provided to the Institute for Land, Water, and Society for research support time. 
Conflicts of Interest: The author declares no conflict of interest. The research supporting body had no role in the study design, data collection, analyses, manuscript writing, or decision to publish results.

\section{References}

1. Horlick-Jones, T.; Prades, A. Translating between social worlds of policy and everyday life. Public Underst. Sci. 2015, 24, 811-826. [CrossRef]

2. Alexandra, J. Evolving governance and contested water reforms in Australia's Murray Darling Basin. Water 2018, 10, 113. [CrossRef]

3. Gibbs, L.M. Just add water: Colonisation, water governance, and the Australian Inland. Environ. Plan. A 2009, 41, 2964-2983. [CrossRef]

4. Alexandra, J.; Marshall, G.R. Institutional path dependence and environmental water recovery in Australia's Murray-Darling Basin. Water Altern. 2016, 9, 679-703.

5. Alexandra, J.; Martin, P. “Tax Returns for Water": Satellite-Audited Statements Can Save the Murray-Darling; The Conversation: Parkville, Australia, 2017.

6. Curtis, A.; McDonald, S.; Mendham, E.; Sample, R. Understanding the Social Drivers for Natural Resource Management in the Wimmera Region; ILWS: Albury, Australia, 2008.

7. Yearley, S. Nature and the environment in science and technology studies. In The Handbook of Science and Technology Studies; Hackett, E.J., Amsterdamska, O., Lynch, M., Wajcman, J., Eds.; MIT Press: Cambridge, MA, USA, 2008; pp. $921-947$.

8. Crase, L.; Connor, J.; Michaels, S.; Cooper, B. Australian water policy reform. Clim. Policy 2020, 20, 641-651. [CrossRef]

9. Sennett, R. Building and Dwelling; Penguin: London, UK, 2018.

10. Kennedy, C.; Cuddihy, J.; Engel-Yan, J. The changing metabolism of cities. J. Ind. Ecol. 2007, 11, 43-59. [CrossRef]

11. Zander, K.; Wilson, T.; Garnett, S. Understanding the role of natural hazards in internal labour mobility in Australia. Weather Clim. Extrem. 2020, 29, 10-21. [CrossRef]

12. Dandy, J.; Horwitz, P.; Campbell, R.; Drake, D.; Leviston, Z. Leaving home: Place attachment and decisions to move in the face of environmental change. Reg. Environ. Chang. 2019, 19, 615-620. [CrossRef]

13. Kelman, K.; Upadhyay, H.; Simonelli, A.C.; Arnall, A.; Mohan, D.; Lingaraj, G.J.; Nair, S.; Webersik, C. Here and now: Perceptions of Indian Ocean islanders on the climate change and migration nexus. Hum. Geogr. 2017, 99, 284-303. [CrossRef]

14. Black, R.; Adger, W.N.; Arnell, N.W.; Dercon, S.; Geddes, A.; Thomas, D. Migration and global environmental change. Glob. Environ. Chang. 2011, 21, S1-S2. [CrossRef]

15. Khorasani, M.; Zarghamfard, M. Analyzing the impacts of spatial factors on livability of peri-urban villages. Soc. Indic. Res. 2018, 136, 693-717. [CrossRef]

16. Swyngedouw, E.; Heynen, N.C. Urban Political Ecology, Justice and the Politics of Scale; Oxford University: Oxford, UK, 2003.

17. Chan, K.M.A.; Agard, J.; Liu, J. Pathways Towards a Sustainable Future; IPBES Global Assessment on Biodiversity and Ecosystem Services: Paris, France, 2019; Chapter 5.

18. Bashan, D.; Colléony, A.; Shwartz, A. Urban versus rural? The effects of residential status on species identification skills and connection to nature. People Nat. 2021, 3, 347-358. [CrossRef]

19. Thomson, J. Few Winners in COVID State of Origin. Australian Financial Review. 2021, p. 56. Available online: https: //www.afr.com/chanticleer/few-winners-in-covid-state-of-origin-20210103-p56rge (accessed on 8 September 2021).

20. Crampton, A.; Ragusa, A.T. Exploring perceptions and behavior about drinking water in Australia \& New Zealand. Hydrology 2016, 3, 8-22.

21. Ellem, K.; Baidawi, S.; Dowse, L.; Smith, L. Services to young people with complex support needs in rural and regional Australia: Beyond a metro-centric response. Child. Youth Serv. Rev. 2019, 99, 97-106. [CrossRef]

22. Ragusa, A.T.; Crampton, A. Cruising for better air quality: Australian clean air submissions, issues, \& recommendations. E3S Web Conf. 2020, 158, 02003. [CrossRef]

23. Crampton, A.; Ragusa, A.T. Microbial load and related health risks associated with self-managed rural water supplies in NSW, Australia. Internet J. Microbiol. 2010, 9, 1-7.

24. Crampton, A. Water: An essential resource and potential health risk. In Rural Lifestyles, Community Well-Being and Social Change: Lessons from Country Australia for Global Citizens; Ragusa, A.T., Ed.; Bentham Science: Sharjah, United Arab Emirates, 2014; pp. 473-514.

25. National Rural Health Alliance. Mental Health in Rural and Remote Australia. Available online: http://ruralhealth.org.au/sites/ default/files/publications/nrha-mental-health-factsheet-2017b.pdf (accessed on 30 August 2021).

26. National Rural Health Alliance. Poverty in Rural and Remote Australia. Available online: http://ruralhealth.org.au/sites/ default/files/publications/nrha-factsheet-povertynov2017.pdf (accessed on 30 August 2021).

27. Australian Institute of Health and Welfare. Australia's Health 2016; Cat. no. AUS 199; AIHW: Canberra, Australia, 2016.

28. Australian Institute of Health and Welfare. Australia's Health 2010; Cat. no. AUS 122; AIHW: Canberra, Australia, 2010.

29. Pugh, R.; Cheers, B. Rural Social Work; Policy Press: Bristol, UK, 2010.

30. Bourke, L.; Sheridan, C.; Russell, U.; Jones, G.; DeWitt, D.; Liaw, S.T. Developing a conceptual understanding of rural health practice. Aust. J. Rural Health 2004, 12, 181-186. [CrossRef] [PubMed]

31. Rajkumar, S.; Hoolahan, B. Remoteness and issues in mental health care. Epidemiol. Psichiatr. Soc. 2004, 13, 78-82. 
32. Roberts, L.; Hassan, A.; Elamer, A.; Nandy, M. Biodiversity and extinction accounting for sustainable development: A systematic literature review and future research directions. Bus. Strateg. Environ. 2021, 30, 705-720. [CrossRef]

33. Westwood, M.; Cavender, N.; Meyer, A.; Smith, P. Botanic garden solutions to the plant extinction crisis. Plants People Planet. 2021, 3, 22-32. [CrossRef]

34. Spataru, A.; Faggian, R.; Docking, A. Principles of multifunctional agriculture for supporting agriculture in metropolitan peri-urban areas: The case of Greater Melbourne. Australia. J. Rural Stud. 2020, 74, 34-44. [CrossRef]

35. Rawluk, A.; Curtis, A. "A Mirror and a Lamp": The role of power in the rural landscape trajectory of the Ovens region of Australia. Soc. Nat. Resour. 2017, 30, 949-963. [CrossRef]

36. Gill, N.; Klepeis, P.; Chisholm, L. Stewardship among lifestyle oriented rural landowners. J. Environ. Plan. Manag. 2010, 53, 317-334. [CrossRef]

37. Garnaut, R. The Garnaut Climate Change Review; Cambridge University Press: Cambridge, UK, 2008.

38. Mendham, E.; Curtis, A. Taking over the reins: Trends and impacts of changes in rural property ownership. Soc. Nat. Resour. 2010, 23, 653-668. [CrossRef]

39. Kells, S. Robber Barons and High-Speed Traders Dominate Australia's Water Market. The Conversation. 2021. Available online: https: / / theconversation.com/robber-barons-and-high-speed-traders-dominate-australias-water-market-166422 (accessed on 1 September 2021).

40. Winterburton, R.; Warburton, J. Does place matter? Rural Soc. 2011, 3, 2-6.

41. Horton, G.; Hanna, L.; Kelly, B. Drought, drying and climate change. Australas. J. Ageing 2010, 29, 2-7. [CrossRef]

42. Davis, S.; Bartlett, H. Healthy ageing in rural Australia. Australas. J. Ageing 2008, 27, 56-60. [CrossRef]

43. Brodie, J.F.; Lieberman, S.; Moehrenschlager, A.; Redford, K.H.; Rodríguez, J.P.; Schwartz, M.; Seddon, P.J.; Watson, J.E.M. Global policy for assisted colonization of species. Science 2021, 372, 456-458. [CrossRef]

44. McArthur, J.; Robin, E. Victims of their own (definition of) success: Urban discourse and expert knowledge production in the liveable city. Urban Stud. 2019, 56, 1711-1728. [CrossRef]

45. Harvey, J.M.A.; Witlox, F.; Tribby, C.P. Developing context-sensitive livability indicators for transportation planning. J. Transp. Geogr. 2013, 26, 51-64.

46. Reeder, R. Recent changes advance new markets and livability initiatives. Rural Cond. Trends 2011, 11, 48-53.

47. Pandey, R.U.; Garg, Y.K.; Bharat, A.A. framework for evaluating residential built environment performance for livability. India J. 2010, 7, 12-20.

48. Norris, T.; Pittman, M. The healthy communities movement and the coalition for healthier cities and communities. Public Health Rep. 2000, 115, 118-124. [CrossRef] [PubMed]

49. Serrao-Neumann, S.; Renouf, M.A.; Morgan, E.; Kenway, S.J.; Choy, D.L. Urban water metabolism information for planning water sensitive city-regions. Land Use Policy 2019, 88, 104144. [CrossRef]

50. Renouf, M.A.; Kenway, S.J.; Lam, K.L.; Weber, T.; Roux, E.; Serrao-Neumann, S.; Morgan, E. Understanding urban water performance at the city-region scale using an urban water metabolism evaluation framework. Water Res. 2018, 137, 395-406. [CrossRef]

51. Vietz, G.J.; Rutherfurd, I.D.; Fletcher, T.D.; Walsh, C.J. Thinking outside the channel: Challenges and opportunities for protection and restoration of stream morphology in urbanizing catchments. Landsc. Urban Plan. 2016, 145, 34-44. [CrossRef]

52. Brown, R.; Ashley, R.; Farrelly, M. Political and professional agency entrapment: An agenda for urban water research. Water Resour. Manag. 2011, 25, 4037-4050. [CrossRef]

53. Wong, T.H.F.; Brown, R.R. The water sensitive city: Principles for practice. Water Sci. Technol. 2009, 60, 673-682. [CrossRef] [PubMed]

54. Creswell, J.W. Research Design; Sage: Thousand Oakes, CA, USA, 2014.

55. Neuman, L.W. Social Research Methods; Pearson Education: Boston, MS, USA, 2014.

56. Sone, S.; Thang, L.L. Staying till the end? Japanese later-life migrants and belonging in Western Australia. Jpn. Stud. 2020, 40, 41-62. [CrossRef]

57. Borsellino, R. The changing migration patterns of the 65+ population in Australia, 1976-2016. Aust. Popul. Stud. 2020, 4, 4-19. [CrossRef]

58. Argent, N.; Smailes, P.; Griffin, T. The amenity complex. Geogr. Res. 2007, 45, 217-232. [CrossRef]

59. Australian Bureau of Statistics. Regional Population 2019-20 Financial Year. Available online: https://www.abs.gov.au/statistics/ people/population/regional-population/2019-2020 (accessed on 4 October 2021).

60. Babbie, E. The Practice of Social Research, 15th ed.; Cengage Learning: Southbank, Australia, 2021.

61. Lichtenstein, M. Younger people want to do it themselves-Self-actualization, commitment, and the reinvention of community. Qual. Sociol. 2019, 42, 181-203. [CrossRef]

62. Clarke, A.E.; Charmaz, K. Grounded Theory and Situational Analysis; Sage: London, UK, 2019.

63. Clarke, A.E. Situational analyses: Grounded theory mapping after the postmodern turn. Interaction 2003, 266, 553-576. [CrossRef]

64. Charmaz, K. Grounded theory: Objectivist and constructivist methods. In Handbook of Qualitative Research; Denzin, N.K., Lincoln, Y.E., Eds.; Sage: Thousand Oaks, CA, USA, 2000; pp. 509-535.

65. Bryant, A.; Charmaz, K. Handbook of Current Developments in Grounded Theory; Sage: London, UK, 2019.

66. Polgar, S.; Thomas, S. Introduction to Research in the Health Sciences; Elsevier: Amsterdam, The Netherlands, 2020. 
67. Braun, V.; Clarke, V. Thematic analysis. In APA Handbook of Research Methods in Psychology; Cooper, H., Ed.; American Psychology Association: Washington, DC, USA, 2012; pp. 1947-1952.

68. Dougherty, M.L.; Olsen, T.D. “They have good devices": Trust, mining, and the microsociology of environmental decision-making. J. Clean. Prod. 2014, 84, 183-192. [CrossRef]

69. Banham, R. Emotion, vulnerability, ontology. Environ. Sociol. 2020, 6, 132-142. [CrossRef]

70. McConnell, K. COVID-19-Population impacts on rural and regional Australia. Interaction 2021, 49, $13-15$.

71. Iaquinta, D.L.; Drescher, A.W. Defining periurban: Understanding rural-urban linkages and their connection to institutional contexts. In Proceedings of the 10th World Congress of the International Rural Sociology Association, Rio de Janeiro, Brazil, 1 August 2000.

72. Lawrence, J.; Quade, D.; Becker, J. Integrating the effects of flood experience on risk perception with responses to changing climate risk. Nat. Hazards 2014, 74, 1773-1794. [CrossRef]

73. Dean, A.J.; Lindsay, J.; Fielding, K.S.; Smith, L.D.G. Fostering water sensitive citizenship-Community profiles of engagement in water-related issues. Environ. Sci. Policy 2016, 55, 238-247. [CrossRef]

74. Greater Shepparton City Council. Submission to Productivity Commission Issue Paper: National Water Reform (2020) Inquiry; Australian Government: Canberra, Australia, 2020. Available online: https://www.pc.gov/inquiries/completed/water-reform2020/submissions (accessed on 3 September 2021).

75. CSIRO and Bureau of Meteorology. State of the Climate 2018. Available online: http:/ / www.bom.gov.au/state-of-the-climate/20 18 (accessed on 8 September 2021).

76. Coleman, S. Australia State of the Environment 2016; Australian Government Department of the Environment and Energy: Canberra, Australia, 2017.

77. Velasco-Muñoz, J.F.; Aznar-Sánchez, J.A.; Batlles-delaFuente, A.; Fidelibus, M.D. Sustainable Irrigation in Agriculture. Water 2019, 11, 1758. [CrossRef]

78. Kögler, F.; Söffker, D. Water (stress) models and deficit irrigation. Ecol. Model. 2017, 361, 135-156. [CrossRef]

79. Parton, K.A.; Tierney, R. Social and economic change in rural communities. In Rural Lifestyles, Community Well-Being and Social Change; Ragusa, A., Ed.; Bentham: Sharjah, United Arab Emirates, 2013; pp. 107-144.

80. Kelly, M.; Rewhorn, S. Counterhegemonic food discourses and geographies of food: Are we losing the rural? In Interdisciplinary Unsettlings of Place and Space; Pinto, S., Hannigan, S., Walker-Gibbs, B., Charlton, E., Eds.; Springer: Berlin/Heidelberg, Germany, 2019; pp. 117-134.

81. Johnson, L. City Farmer: Adventures in Urban Food Growing; Greystone Books Ltd.: Vancouver, BC, Canada, 2011.

82. Larder, N.; Lyons, K.; Woolcock, G. Enacting food sovereignty: Values and meanings in the act of domestic food production in urban Australia. Local Environ. 2014, 19, 56-76. [CrossRef]

83. Gregory, R.; Kozak, R.; St-Laurent, G.P.; Nawaz, S.; Satterfield, S.; Hagerman, S. Under pressure: Conservation choices and the threat of species extinction. Clim. Chang. 2021, 166, 2-21. [CrossRef]

84. Burnley, I.H.; Murphy, P.A. Change, continuity or cycles. J. Popul. Res. 2002, 19, 137-154. [CrossRef]

85. Hugo, G.J. Changing Patterns of Population Distribution in Australia; Special Edition; Australian Population Association: Darwin, Australia, 2002; pp. 1-21.

86. Smailes, P.J.; Argent, N.; Griffin, T.L.C. Rural population density. J. Rural Stud. 2002, 18, 385-404. [CrossRef]

87. Botterill, L.C. Soap Operas, Cenotaphs and Sacred Cows: Countrymindedness and rural policy debate in Australia. Public Policy 2006, 1, 23-36.

88. Meagher, K. Climate Change Means Australia May Have to Abandon Much of Its Farming; The Conversation: Parkville, Australia, 2021; Available online: http:/ / theconversation.com/climate-change-means-australia-may-have-to-abandon-much-of-its-farming166098 (accessed on 11 October 2021). 